\title{
The Doctrine of Court Circumscribe by Criminal Motion Limitations (Comparative Study)
}

\author{
Prof. Dr. Hassoon Ubead Hajeej \\ Professor at University of Babylon \\ Faculty of Law, Department of the Public Law
}

Mr. Muntather Faisal Khadhom

Assistance Lecturer

\begin{abstract}
The main principle in legal process that the criminal court restricted by the motion limits, but that not mean that the court restrict by the crime category held by investigation authority of the act link to the suspect, but it's the court duty to research the criminal motion by all its components and specifications and have to applied law correctly and precisely.

So when the criminal court issue a verdict in the given motion it didn't follows the crime in its specific scope of crime category referred to it but it has the duty to go on all details from all other evidences and from the investigation held by it.

In all way, the court should not punish the suspect on physical action not included in the referred decision or summon paper.

In this paper we will discuss this issue in three section, in the first we will search the doctrine of Court circumscribe by criminal motion limitations and the second for the doctrine of Court circumscribe by personal motion limitations while the third will dedicated to the doctrine of Court circumscribe by factual motion limitations.
\end{abstract}

\section{INTRODUCTION}

The study of the doctrine of Court circumscribe by criminal motion limitations (CML) is a big pillar of judiciary, it has a unique important to the court verdict and to the core of judicial process.

The doctrine was gain enormous important from the set of criminal motion thru investigation stage to referring it to court to make a judgment restricting by personal and substantial limitations.

So the goals of the thesis is rested in the apprehension of right imposition of law as a first step to fulfill criminal justice, this can be done by applying law on facts and persons, the court rule will be understanding first the facts then the law govern the motion to reach the correct implementation to law which is the parties target and the judge duty. So, to clarity the subject we will divide our study to three sections, in the first we will search the doctrine of Court circumscribe by criminal motion limitations and the second for the doctrine of Court circumscribe by personal motion limitations while the third will dedicated to the doctrine of Court circumscribe by factual motion limitations.

\section{DEFINITION OF CML}

One of the main principles of criminal procedures is the separation of the authority of impose charges from the indictment authority. According to that the panel courts cannot give a sentence in a motion unless it reaches to it by the legal processes and by a concern person, and that's limitation adhere to not to investigation and impose a charge authority, instead, it will be to panel court. We will clarify this in following sections.

\subsection{The Meaning of CML}

The real meaning is restricted panel court by the motion context in both personal and material aspects([1]), it also restricted court by the motion facts set by charge authority and the accused person's([2]).So if the penal court makes a sentence within these limitations, then the verdict is lawful, otherwise it will be a void verdict([3]). 
The pursue of criminal motion consider a type of accusation aimed at a specific person submitted to court so the latter can examine it and analyzed it in order to reach its verdict either by indictment or not guilty([4]).

According to that accusation a person is no more than a claim which should put under a close examination and investigation, and this process may lead to discover a new facts or new suspects or even new circumstances related to the motion examined by the court ([5]).

From above we concluded that CML is one of the basic rules governed criminal procedure in courts, and that is for the benefit of defendant([6]).as he will be referred to court to prosecuted based on the same facts he referred by([7]). Although court can brought a new suits against new suspects by referring them to the certain authorities to start a new suit against them ([8]).

The court adherence by a fact present in motion called a panel court substantiality (which represent a objective factor) ([9]). while her adherence by accused persons called a rule of panel court individuality (which represent a subjective factor) ([10]), so the court cannot issue a verdict in a motion didn't submit to her by the legal means ([11]), that mean the court which is approach the case must confine by facts and accused persons in her final verdict as a implementation to the doctrine of separation between authority of accusation and authority of prosecution ([12]).

From all above we reached a conclusion applying that obtain justice can fulfill by adherence when she used its authority in giving a legal statue to the given motion, and that is a keystone procedural rule related to the court mandate in reviewing the motion if she ignore it the issued verdict will be void to violated essential rules part of public order, so this argument can be address by plaintiff in any stage of motion, and it can be address for the first time even before the cassation.

\subsection{Legal Base of CML}

Most of modern legal systems codified the doctrine of CML in their legislations, and it's very rare that doctrine omitted from any panel code and that because of the magnificent important to its roots.

As far as Iraqi panel codes, we notice that the So-called "Baghdadi criminal procedures (abolished) didn't mention it, still, Iraqi court in all his verdicts and judgments ([13]).

But the current law of criminal procedures no. Filled that gap following modern panel code, the sib article A of article (155) cited" It is not permissible to try any defendant who has not been referred to the court"

From the paragraph above its clear that Iraqi legislator referred only to personal limitations without mention substantial limitation, nor did he mention it indirectly in any other text on criminal code, only one think emphasized on that doctrine, and that is the some leading cases settled by Iraqi courts which referred explicitly to court obligation to follow the fact brought to it without extend its authority to examine any other circumstances didn't set before court.

We believed that. Iraqi legislator should mention that doctrine directly and included both personal and substantial limitation because it's have a grave important as a main guarantee of defendant.

But the Iraqi legislator didn't followed that scheme to the end, because he came close to the doctrine in the sub article B of article (187) from criminal procedure law which allow the court to change the charge to the crime referred to it without restriction of the article charge by the authority referred the motion, also its state the court power to modified the charge circumstances and withdrew the charge or drop it.

It's obvious that allowing the court not following CML is came to avoid ignoring it by letting courts prosecute the persons committed illegal act even they not referred to it, like the absence of witness summon to show in court ([14]).

Nor the abstain by the latter to take the oath ordered by court ([15])

In the above cases the court can issue a charge against that person and prosecuted him by change his legal status from witness to suspect, and that could be right if its allowed only in and that is a clear violation of CML.

So we call for the Iraqi legislator to amend sub article A of the article (155) of Iraqi criminal procedures no. To read like this" no suspect should be prosecuted on facts didn't included in referred decision, nor sentence issue against anyone didn't brought to court by panel motion. 


\section{Personal Limitations to CML}

To determine personals limitations we will dissect the subject into two paragraphs. We first deal with definition of personal limitations, and then we will examine the scope of personal limitation of CML.

\subsection{Definition of Personal Limitations to CML}

It can be defined as a restrictions imposed on court when she used its power one the same person(s) which have been referred to by specific authority ([16]).

Anybody else should not be a subject to a verdict even if have a relation to the crime or have a close relation to the suspect ([17]).

That mean the court mandate is one the only on the suspect brought to court by the motion without extend to other, even if there a sold prove that the latter participate in committed the crime ([18]), so we call it personal limitations as its forbid the court from prosecute anyone other than the suspect held by the concern motion ([19]).

That doctrine restricted court by person accused, so it cannot brought new suspects or their partner ([20]), because the main idea is that the prosecution hold on real suspect not others ([21]).

\subsection{The Scope of Personal Limitations of CML}

After we defined the personal limitations of CML, we can concluded the scope of that's limitations, because it rested on the person which the criminal motion brought against him by the authority with the power to do that by law ([22]).

So if the court reached a conclusion to brought another suspect or his accomplice in the crime it couldn't do that by involved him in that motion even if that conclusion reinforced by an official request from the authority which have the power to commence the motion in the first place([23]).

That lead to the fact that the court will proceed only with motion brought to her by legal means ([24]).

The effect of last obliged the court not issue any verdict either innocence or indictment or release in spite of her power in determine crime status, that mean court couldn't prosecute anyone not mention in referring decision even if that person was attend the court procedures or summoned to be a witness or the civil plaintiff([25]).

So if a person referred to a court in a battery account then the victim testified that the one who did the crime is the accused son then the court cannot indicted the son or acquitted his father as the court will followed CML doctrine([26])

And this will not prevent the court from take an action against him, but it will forced it to followed the proper procedures by acquire the investigation authority to initiate the proceeding ([27])

Because the CML enshrined the rights of due process with all its level which will be violated if the accused person referred to court directly without go thru investigation process first ([28])

So if the court issued a sentence against a person didn't referred to it as a suspect then her sentence is a void and will be nulled([29])

Because all the stage of prosecution should be exhausted include elementary investigation with all its guarantees which should precede the appearance in the court ([30])

which may lead to suspect acquittal or not responsibility or that the act he done didn't hold to be a crime, even so the suspect direct challenge about the crime may irritate him and cause him to testified in a way he wouldn't say it otherwise([31]).

From above we may concluded that every suspect can be part of the multi stage suit allow him to know the crime accused to committed so he can prepare his defense according to the stage given, and the court obliged to prosecuted only the person referred to it in the motion while the other suspect can be prosecuted only by following proper proceeding.

As to Iraqi law, it clearly restrict the court by personal limitations to CML so to guarantee the suspect rights and protect justice in courts by provide all rights to him in every stage([32]). 


\section{FActual Limitations to CML}

\subsection{Meaning of Factual Limitations to CML}

Its main meaning is that the court should followed the facts cited in the referred case so it cannot punish a suspect didn't came to court in the motion, even if that assumption enforced by evidence ([33]).

Also one of the main principles of criminal procedure reside in the separation of the authority of accusation and prosecution which prevent the court from change the crime description referred to the court in an issues didn't included in referee decision or summon paper or the arrest warrant([34])

It also mean that the court will restricted which the fact as it came to court even by summon paper or arrest warrant, so it cannot issue a verdict on fact didn't challenge the suspect in the given $\operatorname{motion}([35])$.

Base on above if the court used its power within factual limitation then her judgment is correct ([36]).otherwise it will be null ([37]).

All that mean the investigation authority when proceed motion it will link a certain suspect to specific facts, so the court which address the motion couldn't go beyond the given facts to other facts didn't specified in referee decision or summon paper or even arrest warrant, and that go also for the court of cassation which couldn't that neither([38])

And that validated the second part of CML doctrine, so nobody punished based on facts appear after the motion proceeding or wasn't clear in the time of start the motion proceeding, and the facts we mean are that detailed in the official accusation to the suspect in the referee decision([39])

That mean the criminal motion with what represent of criminal act are in fact the crime realities which the general prosecutor call for indict the perpetrator on proper sentence based on it([40])

All that on the same reasons we discuss in the personal limitations of CML.

To sum up we can say that the Factual limitations to CML mean the court should be obliged by factual fact the suspect referred by it, because in the suspect best interest to be under the full judicial process starting by initial investigation to the given facts so he can prepare his argument concerning the criminal charge and challenge the facts which may lead to his indictment.

\subsection{The Scope of Factual Limitations to CML}

These limitations didn't raised any difficulties about the motion parties, as the doctrine will be violated whenever the court take its proceeding to a person as a perpetrator or his accomplices far as this person didn't by a part of criminal motion by entitled person([41])

But the problems arise in Factual limitations to CML as its need to give a precise concept on that issue.

To clarified, we said that the concept of Factual limitations to CML referred to the crime, and that lead to included all crime elements without covering the criminalized paragraph, or what came with it like the crime circumstance([42]).

In other word, the motion itself included the material and intentional elements and the court should stick to it as they represent the concept of the crime which referred to the actual meaning of the crime, and the later is parts of Factual limitations to CML in the revision of crime category ([43]).

Now we can say that the crime means the criminal act, and the latter in its dynamic concept referred to the crime itself by its elements without the panelized articles ([44]). So the material and intentional crime elements are beyond alteration ([45]).

Also the precise meaning of the crime (the main essence of the crime categorizing) is differ by the panel legal systems, in common law countries which represent the main base for the doctrine show clearly the intend of the courts to restricted the panel judge by all criminal charge details, and this include the acts as well as the panelized paragraphs and all the crime surrounding ([46]).

As to French law and the laws followed it path like Iraq or Egypt, they consider the concept of crime as an act not as a physical mobility ([47]).

Even though these law mentions the personal limitations to CML ([48]). 
But Iraqi criminal code ignored an explicit paragraph of the personal limitations to CML, but we can infer the Iraqi judiciary stand which followed French and Egypt laws ([49]).

So according to this factual limitation if the court issue a verdict of suspect by innocence or indictment on circumstances didn't referred to court based on it, that mean the court make an error([50]).

As its take a role of charging which is not within its mandate, and not followed the referee decision ([51]).

Base on that the court should restricted by the essential motion and forbid from make any modification by adding a new fact didn't mention in the initial investigation or the proceeding ([52]).even if the new fact are provable to the court ([53]).so if the motion set against certain person and link him to a robbery the court could not indict him on other crime ([54]).

The main reason of Factual limitations to CML is guarantee the independence of the crime been referred to the court and the one proceed in by the court, so if the court added anew facts based on its finding then her judgment will be void([55])

And this voidness renders the court verdict without a binding effect ([56])

Also it worth to mention that Factual limitations to CML not an absolute doctrine, as the panel court has the powers within the limitations like the power of modified and alter the crime category which been referred to court ([57]).and modify the criminal charge ([58]).or correct the errors and withdraw the criminal charge or even abolish it ([59]).

From all above we can conclude that Factual limitations to CML restrict the court power and prevent it from violated it, so we call for Iraqi legislator to add a new paragraph No. C to the article No.(155) of Iraqi criminal procedures to be like this" the suspect cannot be prosecuted on a crime didn't mention in the referee decision" so the Iraqi legislator will go along with the trend adopted by comparative Arabian laws.

\section{Conclusion}

After we reach the end in studying limitations to CML its worth to mention a numbers of conclusions and suggestions:

- The main rules governed proceed the motion is the doctrine of the limitations to CML which restricted the court by the persons and facts.

- The limitations of CML didn't mean deprived the court to initiated a motion based on new facts to a new suspects and because the court had the right report the responsible authority to start the judicial process.

- The thesis show that the limitations to CML mean that the court power restricted within the scope of motion and that what the justice call because the essential procedural rules which belong to the court mandate based on criminal motion.

- The doctrine of limitations to CML is base on the referred decision which determine the personal and factual limitation and that forced the court to hold it because the violated it will lead to null the judgment, and that annulment is part of public order which mean it can be call upon in any part of motion stages.

- The Iraqi legislator explicitly cited the personal limitation without factual limitation in sub-article A from article (155) from Iraqi criminal procedures law and we couldn't find any other articles in the same law adopted the factual limitation of CML, but Iraqi courts mention it directly in its judgments. This doctrine is very important as it is main cornerstone of justice guarantee, so we call for Iraqi legislator to amend sub- article A from the article (155) of Iraqi criminal procedures to read like this" the suspect cannot be prosecuted on a crime not mention in referred decision, and the court couldn't issue a verdict to anyone other than the suspect in the given motion".

- The study show that the doctrine of personal limitation of CML only link to the suspect been referred to court as the prosecution held against the actual suspect which the proceeding start against him, not other person. 
- The scope of doctrine of personal limitation of CML is restricted by the person being prosecuted, so any person cannot be persecuted unless there is a motion initiated against him according to law, because doctrine of personal limitation of CML is held in the preserved the procedures rights in its multi-stage process.

- The stage of initial investigation is a main stage of criminal motion and a guarantee to the suspect before referring to the court, but that didn't deprive the court from its power about that person.

- The personal limitations are part of public order which mean it can be call upon in any part of motion stages.

\section{REFERENCES}

[1] Abdufattah Riadh, criminal evidences, Cairo, 2000.

[2] Abdulrahman Jelhem, Legal status of the suspect in Iraqi law and comparative laws, Baghdad.

[3] Abdulsattar Salim, The suspect's guarantees before and thru trial, Doctoral dissertation, Cairo law school.1981.

[4] Abdultawab Muauadh, criminal judgments restoration, Cairo, 1994.

[5] Ali zaki Basha, Main principles of investigation and criminal procedures, Cairo.

[6] Charies H.whitebread: criminal procedure an analysis of cases and concepts, edition 4, 2001.

[7] Dr. abdulfattah Saify, basics of criminal procedures, Alaskendarea, 2004.

[8] Dr. Abdulhameed Alshawarbi, criminal evident in according with judiciary and jurisprudence, Alaskandaria, 1989.

[9] Dr. Adli Ameer Khaled, treatise in procedural guidance in criminal cases procedures, Alaskendarea, 2005.

[10] Dr. Ahmed Fathey Surur, The theory of nullifying in the criminal procedures law, Cairo, 1959.

[11] Dr. Auadh Mohammad Auadh, General principles in criminal procedures, Aliskandaria, 2000.

[12] Dr. Aumar Alsaeed Ramadan, General principles in criminal procedures, Cairo, 1968.

[13] Dr. Hassan Mohammad Raba'a, criminal procedures in Egyptian law, Cairo, 2004.

[14] Dr. Hussein Abdul-Alsaheb, Commentaries on Law of criminal procedures, Vol.1, Vol.1, Baghdad, 2011.

[15] Dr. Mahmood Saleh Aladeley, challenge the judgments, Alaskendarea, 2005.

[16] Dr. Mamoon Mohammad Salameh, criminal procedures in Egyptian law, Cairo, 1988.

[17] Dr. Mohammad Aied Gareeb , legal procedures and its protection guarantee by criminal law, 2000, p.271.

[18] Dr. Mohammad Daher Maruef, Main principles of criminal procedures, Vol.1, Cairo, 2004.

[19] Dr. Ramzi Riadh Auadh, the authority of criminal judge in measuring evidence, Cairo, 2004.

[20] Dr. Saeed Mahmood, Search and Arrest, Egypt, 2006.

[21] Dr.Abdul Adeam Mursi Wazeer, The rule of courts in implements criminal procedures, Cairo , 1978.

[22] Dr.abdul Raheem Alshawarbi, channels of criminal judgments challenges, Cairo, 1988.

[23] Dr.Abdul Rauf Mahdi, Commentaries on general principles of criminal procedures, Cairo, 2003.

[24] Dr.Abdulmunem Abdulraheem Aluadhi, the principles of court restriction by accusation, Cairo, 1973.

[25] Dr.Fakri Abdulrazak Sulby, lectures on Algerian Law of criminal procedures, Amman, 2011.

[26] Dr.Farouk Algailani, lectures on Jordanian and comparative Law of criminal procedures, Beirut, 1995.

[27] Dr.Halaly Abdullah Ahmed, snap accusation in the initial investigation, Cairo, 2002.

[28] Dr.Hassan Saddiq aAlmarsafawi, General principles in criminal procedures, Cairo, 1972.

[29] Dr.Hassun Ubead Hajeej, the doctrine of factual criminal motion, UOB journal of Law sciences, Vol.1 (2010.

[30] Dr.Kamal Abdulwahed Aljuhari, basics of the doctrine of criminal judge authority in making his judgments, Kuwait, 2010. 
[31] Dr.Kamel Alsaeed, Commentary on Law of criminal procedures, Amman, 2008.

[32] Dr.Kamel Alsdeed, Commentary on Iraqi Law of criminal procedures, Amman, 2008.

[33] Dr.Muhammad altarawna, guarantees of human rights in criminal case, Amman, 2003.

[34] Dr.Nidham Taufeiq Almajali, The Scope of personal civil claimer in the criminal cases, Amman, 2006.

[35] Dr.Rauf Ubead, causing of criminal judgments, Cairo, 1987.

[36] Dr.Rauf Ubead, principles of criminal procedures in Egyptian law, Cairo, 2006.

[37] Dr.saeed Hassab -Allah, Commentaries on Law of criminal procedures, Musel, 1990.

[38] Dr.Sami Alnasrawi, study in the principles of criminal procedures, Baghdad, 1978.

[39] Gaston stefani wt: proce jure penale treizieme edition, Dalloz , paris , 1987.

[40] Ghaleb Ubead Khalaf, criminal charge (issue it and modified it), Doctoral dissertation, Baghdad's school of law, 1996.

[41] Haseebah Muhey-Aldean, Suspect's guarantees in the initial investigation, Alaskendarea, 2011.

[42] Ibraheem Almushahedi, Selections of Cassation Court decisions, Baghdad, 1990.

[43] Jawad Alruhaimi, the rules of nullify in Law of criminal procedures, Baghdad, 2006.

[44] Jean Larguire: droit penal, General procedure penale, Dalloz , paris , 1977.

[45] Mahmood Mahmood Mustafa, evidence in criminal cases, Cairo, 1977.

[46] Mohammad Hashim Alqasim, the effect of the judge opinions in law evolution, Journal of the Judiciary, school of law, Kuwait.

[47] Mohammad Muhi-Aldean Auadh, Criminal law(principles and theories, 1980.

[48] Muhammad Musbah Alqadhi, principles of criminal procedures law, p.16., see also Dr. Rauf Ubead, Crime specification, Journal of Almuhamma (Attorney), Egyptian Bar Association, No.1, Cairo , (1956).

[49] Richard card: criminal law, butter worthe, london, 1997.

[50] Salman Ubead Abdullah, Selections of Cassation Court decisions/Juvnile Section, Vol.1, Baghdad, 2012.

[51] Spencer John: La prenurcen procedure penale droit, 1992.

[52] Sulaiman abdul muneam, referring the criminal case from investigation authority to courts, Alaskanaria, 2002.

([1]) Dr.Hassun Ubead Hajeej, the doctrine of factual criminal motion, UOB journal of Law sciences, Vol.1 (2010),p8.

([2]) Ghaleb Ubead Khalaf, criminal charge(issue it and modified it), Doctoral dissertation, Baghdad 's school of law, 1996,p.38.

([3]) Muhammad Musbah Alqadhi, principles of criminal procedures law, p.16., see also Dr. Rauf Ubead, Crime specification, Journal of Almuhamma(Attorney), Egyptian Bar Association, No.1, Cairo, (1956), p.227.

([4]) Dr. Auadh Mohammad Auadh, General principles in criminal procedures, Aliskandaria, 2000, p.861.

([5]) Dr. Saeed Mahmood, Search and Arrest, Egypt, 2006, p.216.

([6]) Dr.Hassun Ubead Hajeej, Op.Cit, p.81.

([7]) Gaston stefani wt: proce jure penale treizieme edition, Dalloz , paris , 1987 , p. 316.

([8]) Ghaleb Ubead Khalaf, Op.Cit, p.38.

([9]) Mohammad Muhi-Aldean Auadh, Criminal law(principles and theories, 1980, p.425., Dr.Abdul Rauf Mahdi, Commentaries on general principles of criminal procedures, Cairo , 2003, p.329.

([10]) Article (155) of Iraqi criminal procedure law, which is similar to of article(207) of Egyptian criminal procedures law, and article(301) of Yemeni criminal procedures law, and article(206) of criminal procedures law in Jordan, and article(268) of Syrian criminal procedures law, and article(231) of French criminal procedures law. 
([11]) Dr. Aumar Alsaeed Ramadan, General principles in criminal procedures, Cairo, 1968, p.74.

([12]) Dr.Hassan Saddiq aAlmarsafawi, General principles in criminal procedures, Cairo , 1972, p.681.

([13]) Decision of Cassation Court No.342/j/1934 in 30/9/1934. also her decision No.119/j/1965 in 5/3/1965, Dr.saeed Hassab -Allah, Commentaries on Law of criminal procedures, Musel, 1990,p.303.

([14]) Sub-article(A) from Article(174) from Iraqi Law of criminal procedures, which cite" if the informed witness didn't attend the court then the court can reissue the summon paper or issue arrest warrant to testify and if he didn't show up the court can punish him.

([15]) The article No.(76) of Iraqi Law of criminal procedures referred to " the court right to punish the witness if he refuse to testified or take the oath"

([16]) Spencer John: La prenurcen procedure penale droit, 1992, p. 11.

([17]) Dr.Farouk Algailani, lectures on Jordanian and comparative Law of criminal procedures, Beirut, 1995, p.559.

([18]) Dr.Fakri Abdulrazak Sulby, lectures on Algerian Law of criminal procedures, Amman, 2011, p.353.

([19]) Dr. Abdulhameed Alshawarbi, criminal evident in according with judiciary and jurisprudence, Alaskandaria, 1989.p.411. also Abdufattah Riadh, criminal evidences, Cairo, 2000, p.189.

([20]) Charies H.whitebread: criminal procedure an analysis of cases and concepts, edition 4, 2001. p. 235.

([21]) Dr. Abdulsattar Salim, The suspect's guarantees before and thru trial, Doctoral dissertation, Cairo law school.1981, p.712.

([22]) Ali zaki Basha, Main principles of investigation and criminal procedures, Cairo , pp.65-66., Dr. Sulaiman abdul muneam, referring the criminal case from investigation authority to courts, Alaskanaria, 2002, p.245.

([23]) Richard card: criminal law, butter worthe, London, 1997, p.396.

([24]) Sub-article(B) if Article(155) from the Iraqi Law of criminal procedures, which illustrated " if the court discover before issuing the verdict that the are other people linked to the crime as a suspects or accomplices and didn't prosecuting them".

([25]) Dr. Hussein Abdul-Alsaheb, Commentaries on Law of criminal procedures, Vol.1, Vol.1, Baghdad, 2011, p.54.

([26]) Jawad Alruhaimi, the rules of nullify in Law of criminal procedures, Baghdad, 2006, p.235.

([27]) Sub-article(B) of article(155) of Iraqi Law of criminal procedures, which illustrate " if the court discover before issue a verdict...it can prosecute the suspect referred to it and asked the investigation authorities take the appropriate legal action against other or deliver the case to investigation authorities to complete its work.

([28]) Dr. Mohammad Aied Gareeb , legal procedures and its protection guarantee by criminal law, 2000, p.271. also: Mahmood Mahmood Mustafa, evidence in criminal cases, Cairo , 1977, p.338.

([29]) Decision of Iraqi Federal Cassation Court, No.561/Juvnile/2009 in 15/7/2009. see also Salman Ubead Abdullah, Selections of Cassation Court decisions/Juvnile Section, Vol.1, Baghdad, 2012, p.179-180, also its verdict No.118/1992 in 31/8/1992. see: Ibraheem Almushahedi, Selections of Cassation Court decisions, Baghdad , 1990,p.11.

([30]) Dr.Nidham Taufeiq Almajali, The Scope of personal civil claimer in the criminal cases, Amman, 2006, p.199. also: Dr.Halaly Abdullah Ahmed, snap accusation in the initial investigation, Cairo, 2002, p.376.

([31]) Abdulrahman Jelhem, Legal status of the suspect in Iraqi law and comparative laws, Baghdad, p.43.

([32]) The sub-article(a) of the article (155) of Iraqi Law of criminal procedures which illustrated " no suspect should be try other than the one referred to it".

([33]) Dr.Faruk Algailani, Op.Cit.p.548.

([34]) Dr.Kamel Alsdeed, Commentary on Iraqi Law of criminal procedures, Amman, 2008, p.585. 
([35]) Dr.Galeb Ubead Kalaf, Op.Cit, p.46.

([36]) Haseebah Muhey-Aldean, Suspect's guarantees in the initial investigation, Alaskendarea, 2011, p.391.

([37]) Dr. Mahmood Saleh Aladeley, challenge the judgments, Alaskendarea, 2005, p.250. also: Dr.Muhammad altarawna, guarantees of human rights in criminal case, Amman , 2003, p.164.

([38]) Dr. Mohammad Daher Maruef, Main principles of criminal procedures, Vol.1, Cairo, 2004, p.168.

([39]) The facts in the referred decision or as they call it "criminal charge" in fact is a summary of initial investigation and its include what the investigation authority reached. See: Dr.Sami Alnasrawi, study in the principles of criminal procedures, Baghdad, 1978, p.456.

([40]) ([40]) Dr. Ahmed Fathey Surur, The theory of nullifying in the criminal procedures law, Cairo, 1959, p.512. also: Dr. Ramzi Riadh Auadh, the authority of criminal judge in measuring evidence, Cairo , 2004, p.461.

([41]) Jean Larguire :droit penal, General procedure penale, Dalloz , paris , 1977 , p.415.

([42]) Dr.Rauf Ubead, causing of criminal judgments, Cairo, 1987, p.523., Abdultawab Muauadh, criminal judgments restoration, Cairo, 1994, p.178.

([43]) Dr. Hassan Mohammad Raba'a, criminal procedures in Egyptian law, Cairo , 2004, p.707. also: Dr. abdulfattah Saify, basics of criminal procedures, Alaskendarea, 2004,p.294.

([44]) Dr.Kamal Abdulwahed Aljuhari, basics of the doctrine of criminal judge authority in making his judgments, Kuwait, 2010, p.294.

([45]) Dr. Mamoon Mohammad Salameh, criminal procedures in Egyptian law, Cairo, 1988, pp.145146.

([46]) it's worth to mention that the restriction to the case mean restriction to the fact itself, because the case is irreplaceable with other one for the differences of the identity in spite of the similarities in the facts, like inferred robbery from other robbery.

([47]) Dr.Abdulmunem Abdulraheem Aluadhi, the principles of court restriction by accusation, Cairo, 1973, p.216., Mohammad Hashim Alqasim, the effect of the judge opinions in law evolution, Journal of the Judiciary, school of law, Kuwait, Vol.1, No.1, p.296.

([48]) Sub-article (A) Article (155) of Iraqi criminal procedure law.

([49]) Decision of Cassation Court No.118/1992 in 31/8/1992(unpublished), also her decision No.31/2006 in 27/6/2006, and her decision No.56/2006 in 31/7/2006. see: Salman Ubead Abdullah, Selections of Cassation Court decisions/ criminal section, Baghdad, 2009, p.20.

([50]) Dr. Adli Ameer Khaled, treatise in procedural guidance in criminal cases procedures, Alaskendarea, 2005, p.342.

([51]) Dr.Kamel Alsaeed, Commentary on Law of criminal procedures, Amman, 2008, p.268.

([52]) Dr. Hassan Mohammad Rabie, Op.Cit, p.77.

([53]) Dr.Rauf Ubead, principles of criminal procedures in Egyptian law, Cairo, 2006, p.618.

([54]) Dr. Hussein Abdul-Alsaheb, Op.Cit, p.62.

([55]) Dr.Muhammad altarawna, Op.Cit.p.164.

([56]) Dr.Abdul Adeam Mursi Wazeer, The rule of courts in implements criminal procedures, Cairo, 1978,p.211. also: Dr.abdul Raheem Alshawarbi, channels of criminal judgments challenges, Cairo, 1988, p.91.

([57]) Sub-article (B) Article (187) of Iraqi criminal procedure law.

([58]) Sub-article (A) Article (190) of Iraqi criminal procedure law.

([59]) Sub-article (B) Article (190) of Iraqi criminal procedure law. 


\section{AUTHORS' BIOGRAPHY}

\section{Prof. Dr. Hassoon Ubead Hajeej,}

- I start working in 2002 at Babylon University College of law.

- I published 4 books in Iraq.

- I participated in the four conferences and four scientific seminars in different universities in Iraq.

- I published 27 articles in Iraq.

- I am head of public law at university of Babylon branch in college of law.

Mr. Muntather Faisal Khadhom,

- Assistance Lecturer. 